\title{
Contribution of Macrophages to Proteolysis and Plasmin Activity in Ewe Bulk Milk
}

\author{
M. Caroprese, A. Marzano, L. Schena, R. Marino, A. Santillo, and M. Albenzio ${ }^{1}$ \\ Dipartimento PRIME and Istituto per la Ricerca e le Applicazioni Biotecnologiche per la Sicurezza e la Valorizzazione \\ dei Prodotti Tipici e di Qualità (BIOAGROMED), Università di Foggia, 71100, Italy
}

\begin{abstract}
A total of 225 bulk sheep milk samples were collected from 5 intensively managed flocks during early, mid, and late lactation to assess the contribution of macrophages to the regulation of the plasmin-plasminogen system. Samples were analyzed for composition, somatic cell counts, milk renneting characteristics, and for plasmin (PL), plasminogen (PG), and plasminogen activators (PA) activities. Isolation of macrophages from milk was performed using a magnetic positive separation and mouse antiovine macrophage antibody; separated cells were lysed by several freeze-thaw cycles, and activity of urokinase PA (u-PA) was determined. Plasmin activity decreased during lactation (42.06 \pm 0.66 , early; $31.29 \pm 0.66$, mid; $28.19 \pm 0.66 \mathrm{U} /$ $\mathrm{mL}$, late). The reduction in PL activity recorded in the mid and late lactation milk matched the increase in PG:PL ratio. The activity of PA increased throughout lactation; the highest value being recorded in the late lactation milk ( $260.20 \pm 8.66 \mathrm{U} / \mathrm{mL})$. Counts of isolated and concentrated macrophages were higher in early and mid lactation milk (3.89 \pm 0.08 and $3.98 \pm 0.08 \log _{10}$ cells $/ \mathrm{mL}$, respectively) than in late lactation milk (3.42 $\pm 0.08 \log _{10}$ cells $/ \mathrm{mL}$ ). Stage of lactation did not influence the activity of u-PA detected in isolated macrophages. The activity of u-PA associated with isolated milk macrophages only minimally contributed to total PA activity detected in milk. Proteolytic enzymes, associated with isolated macrophages, act on $\alpha$-casein hydrolysis, as shown by urea-PAGE electrophoresis analysis. Somatic cell counts did not exceed 600,000 cells/ $\mathrm{mL}$, and this threshold can be considered a good index of health status of the flock and of the ability of milk to being processed. Our results lend support to the hypothesis that macrophages in ewe bulk milk from healthy flocks only slightly contribute to the activation of the PL-PG system.
\end{abstract}

Received October 19, 2006.

Accepted January 24, 2007.

${ }^{1}$ Corresponding author: m.albenzio@unifg.it
Key words: macrophage, bulk milk, plasmin, plasminogen activator

\section{INTRODUCTION}

Plasmin is the main native proteolytic enzyme in milk and is part of a complex protease-protease inhibitor system in milk, consisting of plasmin (PL); its inactive form, plasminogen (PG); PG activators (PA), which convert PG to PL, PA inhibitor (PAI), which inhibits PA activity; and PL inhibitor, which inhibits PL activity (Nielsen, 2003).

The PL system derives from blood, where it is involved in the degradation of fibrin clots (Sidelmann et al., 2000); in milk PL, PG, and PA are associated with the CN micelles (Politis, 1996). Tissue-type PA (t-PA) appear associated with $\mathrm{CN}$ fractions, whereas urokinase-type activators (u-PA) appear associated with somatic cell fraction (Politis, 1996). The most important inhibitors of PL are $\alpha_{2}$-anti-PL, a specific PL inhibitor, and $\alpha_{2}$-macroglobulin, a nonspecific inhibitor that reacts with most proteases. Christensen et al. (1995) estimated that there are at least 6 inhibitors of PL. Two types of PAI have been identified in milk, PAI-1 and PAI-2 (Politis, 1996).

Evidence exists for a close association between changes in the PG-PL system and gradual involution of the mammary gland in late lactation (Politis, 1996; Silanikove et al., 2005). Milk somatic cells can convert PG to PL, and, in particular, milk macrophages, which are a type of somatic cell, produce u-PA in vitro (Politis et al., 1991). In sheep, blood macrophages and neutrophils express a specific u-PA (Politis et al., 2002); also, in individual ewe milk samples with high SCC, PL activity has been found to be dependent on PA connected to milk macrophages (Albenzio et al., 2004).

Bulk milk traits (i.e., SCC and composition) provide reliable indications for milk quality and for its suitability for consumption and processing. Ewe milk is used almost totally for cheese manufacture so that indigenous proteolytic enzymes, mainly PL, play a major role in milk CN breakdown, thus reducing the ability of milk to be processed into cheese (Albenzio et al., 2005). 
Therefore, this study was undertaken to investigate the contribution of milk macrophages to $\mathrm{CN}$ hydrolysis and the conversion of PG into PL in ewe bulk milk throughout lactation.

\section{MATERIALS AND METHODS}

\section{Experimental Design and Milk Sampling}

The experiment was conducted from March to July 2005 in 5 intensively managed commercial flocks of Comisana ewes in southern Italy and consisting of about 200 ewes per flock. Ewes involved in the trial had lambed in the winter of 2005 and were in parity 2 to 4. Ewes were housed on straw litter; they grazed in the morning and were supplemented with hay and concentrate. Ewes were healthy at the beginning of the experiment and were monitored for health by veterinarians throughout the study. In each flock, 5 sampling cycles were performed during early, mid, and late lactation ( $<70 \mathrm{~d}$, from 110 to $130 \mathrm{~d}$, and $>160 \mathrm{~d}$ in lactation, respectively). Ewes exhibiting any sign of mastitis were excluded from milking. The ewes were milked at 0800 and $1500 \mathrm{~h}$ using a highline milking machine $(44 \mathrm{kPa}$; 120 pulsations/min). Both milkings were included in each sampling cycle. Milk samples were collected in 200-mL sterile plastic containers, carried to the laboratory by transport tankers at $4^{\circ} \mathrm{C}$, and immediately analyzed. For each sampling cycle, samples were collected in triplicate. A total of 225 bulk milk samples were collected and analyzed for fat, total protein, and lactose (MilkoScan 133B; Foss Electric, Hillerød, Denmark). Total N, noncasein N (NCN), and NPN were determined by standard procedures using the Kjeldahl method (IDF, 1993). Casein $\mathrm{N}$ was calculated as the difference between total N and NCN; whey N was calculated as the difference between NCN and NPN. All $\mathrm{N}$ data were expressed as protein equivalent using a conversion factor of 6.38. Somatic cell count was determined using a Fossomatic 90 (Foss Electric) according to the International Dairy Federation standard (IDF, 1995). Renneting characteristics (clotting time, rate of clot formation, and clot firmness after $30 \mathrm{~min}$ ) were measured by a Foss Electric formagraph. Plasmin and $\mathrm{PG}$ activities in milk were determined by the method of Baldi et al. (1996); the dissociation of PL and PG from $\mathrm{CN}$ micelles was obtained by incubation of skim milk with $50 \mathrm{~m} M$ of $\varepsilon$-aminocaproic acid for $2 \mathrm{~h}$ at room temperature (Korycka-Dahl et al., 1983). The solution consisted of $250 \mu \mathrm{L}$ of $0.1 M$ Tris-HCl buffer, $\mathrm{pH} 7.4$; $0.6 \mathrm{~m} M$ Val-Leu-Lys-p-nitroanilide (V7127, Sigma Chemical Co., Milan, Italy); 30 plough units $(2.5 \mu \mathrm{L})$ of urokinase (U0633, Sigma Chemical Co.); and $30 \mu \mathrm{L}$ of milk serum. Plasmin activity was measured in the same solution without adding urokinase. Plasminogen activity was the difference. A similar mixture without sample was used as negative control. Activity of total u-PA was performed in a solution containing $100 \mathrm{mM}$ Tris buffer, $\mathrm{pH} 8.0 ; 50 \mu \mathrm{g} / \mathrm{mL}$ of PG (P5661, Sigma Chemical Co.); $0.6 \mathrm{~m} M$ Val-Leu-Lys- $p$-nitroanilide (Sigma Chemical Co.); and $10 \mu \mathrm{L}$ of sample. The reaction solution was incubated at $37^{\circ} \mathrm{C}$ for up to $3 \mathrm{~h}$, and absorbance at $405 \mathrm{~nm}$ was measured at 30-min intervals using a microtiter plate reader. A sample without PG served as a negative control. One unit of PL, PG, and total u-PA activity was defined as the amount of the enzyme that produces a change of 0.1 in absorbance at $405 \mathrm{~nm}$ in $60 \mathrm{~min}$.

\section{Macrophage Isolation and Total Macrophage-Associated u-PA Activity}

Milk samples $(\sim 400 \mathrm{~mL})$ were centrifuged at $2,000 \times$ $g$ for $30 \mathrm{~min}$ at $4^{\circ} \mathrm{C}$; then the fatty fraction and supernatant were removed. Cells from the bottom layer were suspended in $500 \mu \mathrm{L}$ of PBS ( $\mathrm{pH} 7.4$ ) containing $0.02 \%$ $\mathrm{NaN}_{3}$ and centrifuged twice $\left(400 \times g\right.$ for $15 \mathrm{~min}$ at $\left.4^{\circ} \mathrm{C}\right)$ to concentrate cells. A cell concentration of at least $1 \times$ $10^{7}$ cells $/ \mathrm{mL}$ was obtained, which was measured using Fossomatic 90 (Foss Electric).

Isolation of macrophages from milk cells was performed by a magnetic positive separation (EasySep, StemCell Technologies, Vancouver, Canada) using mAB mouse IgG (MCA919; Serotec, Oxford, UK) directed against macrophage surface antigens. The assay was performed according to Caroprese et al. (2006). After separation of macrophages, cells were lysed by at least 3 freeze-thaw cycles. Activity of u-PA was determined in lysed cells as previously reported. The mixture was incubated for up to $3 \mathrm{~h}$, and absorbance at $405 \mathrm{~nm}$ was measured at 30-min intervals using a microtiter plate reader. A sample without PG served as a control.

\section{Proteolytic Activity of Macrophages on $\mathrm{Na}$ Caseinate}

A $4 \%$ ovine $\mathrm{Na}$ caseinate in a Tris buffer solution, $\mathrm{pH} 8.0$, was used to investigate the proteolytic activity of lysed macrophages during early, mid, and late lactation. Whole $\mathrm{CN}$ and $\mathrm{Na}$ caseinate were prepared from a sample of ovine skim milk according to Mulvihill and Fox (1977). Sodium caseinate was dissolved in $0.1 \mathrm{M}$ Tris buffer (Sigma Chemical Co.) and $0.05 \% \mathrm{NaN}_{3}$. Lysed macrophages were incubated in $\mathrm{Na}$ caseinate buffer from 0 to $24 \mathrm{~h}$ at $37^{\circ} \mathrm{C}$. The effects of macrophage proteolytic activity on $\mathrm{Na}$ caseinate were evaluated by urea-PAGE using a Protean II xi vertical slab gel unit (Bio-Rad, Watford, UK). The stacking and resolving gel system was prepared as described by Andrews (1983). 
Table 1. Least squares means \pm SEM of chemical composition and renneting characteristics of ewe bulk milk

\begin{tabular}{lcccccc}
\hline & \multicolumn{3}{c}{ Stage of lactation } & & \\
\cline { 2 - 4 } Item & Early & Mid & Late & SEM & Effect \\
\hline pH & 6.69 & 6.62 & 6.7 & 0.05 & NS \\
Fat, \% & 5.6 & 6.16 & 6.26 & 0.2 & NS \\
Protein, \% & 5.03 & 5.17 & 4.77 & 0.16 & NS \\
Lactose, \% & $4.51^{\mathrm{a}}$ & $4.37^{\mathrm{a}}$ & $4.04^{\mathrm{b}}$ & 0.05 & $* * *$ \\
CN, \% & 3.64 & 4.01 & 3.53 & 0.14 & NS \\
Whey protein, \% & $1.08^{\mathrm{a}}$ & $0.88^{\mathrm{b}}$ & $0.88^{\mathrm{b}}$ & 0.03 & $* *$ \\
SCC log cells/mL & $5.25^{\mathrm{b}}$ & $5.72^{\mathrm{a}}$ & $5.29^{\mathrm{b}}$ & 0.09 & $* *$ \\
Clotting time, min & $22.05^{\mathrm{b}}$ & $16.94^{\mathrm{c}}$ & $28.86^{\mathrm{a}}$ & 0.6 & $* * *$ \\
Rate of clot formation, min & $1.76^{\mathrm{b}}$ & $1.47^{\mathrm{b}}$ & $2.57^{\mathrm{a}}$ & 0.16 & $* *$ \\
Clot firmness at 30 min, mm & $39.53^{\mathrm{b}}$ & $52.09^{\mathrm{a}}$ & $30.05^{\mathrm{b}}$ & 2.8 & $* *$ \\
\hline
\end{tabular}

${ }^{\mathrm{a}-\mathrm{c}}$ Means within a row with different superscripts $\operatorname{differ}(P<0.05)$.

$* * P<0.01 ; * * * P<0.001$.

The gels were stained using a modification of the method of Blakesley and Boezi (1977) with Coomassie Brilliant Blue G250. The distained gels were acquired by the Gel Doc EQ system (Bio-Rad) using a white light conversion screen and analyzed with the Quantity One software (Bio-Rad) to determine the signal intensity (optical density) of the defined bands. Identification of bands was done by comparison with the $\mathrm{Na}$ caseinate standard. The relative quantity of each defined band in a single lane was determined as the percentage of the optical density, considering $100 \%$ the sum of the optical density measured in all bands of that lane.

\section{Statistical Analyses}

Data were processed by ANOVA, using the GLM procedure of SAS Institute (1999). The model utilized was:

$$
\mathrm{y}_{\mathrm{ij}}=\mu+\alpha_{\mathrm{i}}+\beta_{\mathrm{ij}}+\varepsilon_{\mathrm{ij}},
$$

where $\mu=$ the overall mean; $\alpha=$ the effect of stage of lactation ( $\mathrm{i}=1$ to 3 ); $\beta$ = flock variation within stage of lactation; and $\varepsilon=$ the error.

The variation due to stage of lactation was tested. Bulk milk SCC and isolated macrophage counts were transformed into logarithms to normalize their frequency distributions before performing statistical analysis. Percentage composition of the CN and CN degradation products was tested for stage of lactation, time of incubation, and their interaction. When significant effects were found (at $P<0.05$ ), the Student $t$-test was used to locate significant differences between means.

\section{RESULTS AND DISCUSSION}

Composition of ovine bulk milk was not subjected to severe changes during lactation, probably because of both the good health of ewe udders through lactation and the bulk milk ability to reduce fluctuations of individual milk samples. Indeed, no differences were observed for $\mathrm{pH}$ values and for fat, protein, and $\mathrm{CN}$ content in milk during lactation (Table 1). Stage of lactation influenced the lactose content, which was lower in late lactation than in early and mid lactation $(P<$ 0.001 ), and the whey protein content, which decreased from early to mid and late lactation $(P<0.01)$. Somatic cell count was affected by stage of lactation $(P<0.01)$, the highest SCC being detected in the mid lactation milk. Moreover, SCC did not exceed 600,000 cells $/ \mathrm{mL}$, suggesting this is an indicator of good udder health and good milk characteristics for cheese making (Sevi et al., 1999). Considering the good milk quality, as suggested by the SCC, and whey protein concentrations recorded in the late lactation milk, the decrease in the lactose content during late lactation could be due to the reduction in milk yield with advancing lactation and the increase of microbial fermentation in summer milk (Sevi et al., 2004; Albenzio et al., 2005). Stage of lactation affected milk-coagulating behavior, with the shortest clotting time $(P<0.001)$ in mid lactation milk. Rate of clot formation was highest $(P<0.01)$ in late lactation, whereas curd firmness was highest in mid lactation $(P$ $<0.01$ ). The reduction of milk-renneting traits with advancing lactation agrees with Sevi et al. (2003).

Count of isolated and concentrated macrophages was higher $(P<0.01$; Table 2$)$ in early and mid than in late lactation milk. When lysed macrophages were incubated on $\mathrm{Na}$ caseinate, changes in percentage composition of intact $\mathrm{CN}$ and $\mathrm{CN}$ degradation products $(\gamma-\mathrm{CN}$ and $\alpha$-CN products) after $24 \mathrm{~h}$ of incubation were observed (Table 3), according to the electrophoretic profile (Figure 1). An effect $(P<0.05)$ of stage of lactation was found for $\alpha$-CN products, whereas no significant changes were found for $\alpha$-, $\gamma$ - and $\beta$-CN. After $24 \mathrm{~h}$ of incubation, $\beta$-CN did not undergo appreciable degradation, whereas $\alpha$-CN underwent hydrolysis (about 20\%), suggesting that the former is more resistant to the enzymes associated with macrophages isolated from ewe bulk milk. A more intense hydrolysis of the $\alpha$-CN was observed in early than in late lactation, consistent with the levels of isolated macrophages, and resulted in a higher amount of $\alpha$-CN degradation products, suggesting that the enzymes associated with macrophages could contribute to $\mathrm{CN}$ breakdown in ewe bulk milk with $<600,000$ cells $/ \mathrm{mL}$. Macrophages are a somatic cell population whose main physiological function is to defend the udder from infection and contain lysosomes with active proteolytic enzymes as elastase, collagenase, and cathepsins (Kelly and McSweeney, 2003).

Stage of lactation influenced $(P<0.001)$ the total PA activity detected in milk, whereas no differences were found for u-PA activity detected in isolated macro- 
Table 2. Least squares means \pm SEM of plasmin, plasminogen, plasminogen:plasmin, total plasminogen activator (PA), total macrophage-associated urokinase-PA (u-PA), and macrophage counts in ewe bulk milk during lactation

\begin{tabular}{lcccccc}
\hline & \multicolumn{3}{c}{ Stage of lactation } & & \\
\cline { 2 - 4 } Item & Early & Mid & Late & SEM & Effect \\
\hline Plasmin, U/mL & $42.05^{\mathrm{a}}$ & $31.29^{\mathrm{b}}$ & $28.19^{\mathrm{c}}$ & 0.66 & $* * *$ \\
Plasminogen, U/mL & $4.77^{\mathrm{c}}$ & $38.91^{\mathrm{a}}$ & $31.51^{\mathrm{b}}$ & 1.07 & $* * * *$ \\
Plasminogen:plasmin & $0.12^{\mathrm{b}}$ & $1.31^{\mathrm{a}}$ & $1.16^{\mathrm{a}}$ & 0.05 & $* * *$ \\
Total PA, U/mL & $37.43^{\mathrm{c}}$ & $76.53^{\mathrm{b}}$ & $260.20^{\mathrm{a}}$ & 8.66 & $* * *$ \\
Total macrophage-associataed u-PA, U/mL & 7.07 & 6.75 & 6.09 & 1.41 & NS \\
Macrophage count, $\log _{10}$ cells/mL & $3.89^{\mathrm{a}}$ & $3.98^{\mathrm{a}}$ & $3.42^{\mathrm{b}}$ & 0.08 & $* *$ \\
\hline
\end{tabular}

${ }^{\mathrm{a}-\mathrm{c}}$ Means within a row with different superscripts differ $(P<0.05)$.

$* * P<0.01 ; * * * P<0.001$.

phages (Table 2). In a previous study, Albenzio et al. (2004) found a positive relation between PG conversion and the concentration of macrophages in individual ewe milk with high SCC and ascribed such a relation to the activity of u-PA associated with the macrophage membranes. The majority of the cell associated u-PA in ovine macrophages and neutrophils is bound to a specific u-PA receptor of the cell membrane. Resting macrophages and neutrophils isolated in sheep blood have numerous free and unoccupied u-PA binding sites on their cell membrane, so they produce very low amounts of u-PA (Politis et al., 2002). In this study, macrophage-associated u-PA activity (Table 2) was lower than total PA activity in milk throughout lactation. In addition, the activity of u-PA detected in milk macrophages remained relatively constant, whereas total PA activity increased markedly with advancing lactation, suggesting u-PA associated with macrophages only slightly contributed to total PA activity. Further investigations are needed to verify the role played by

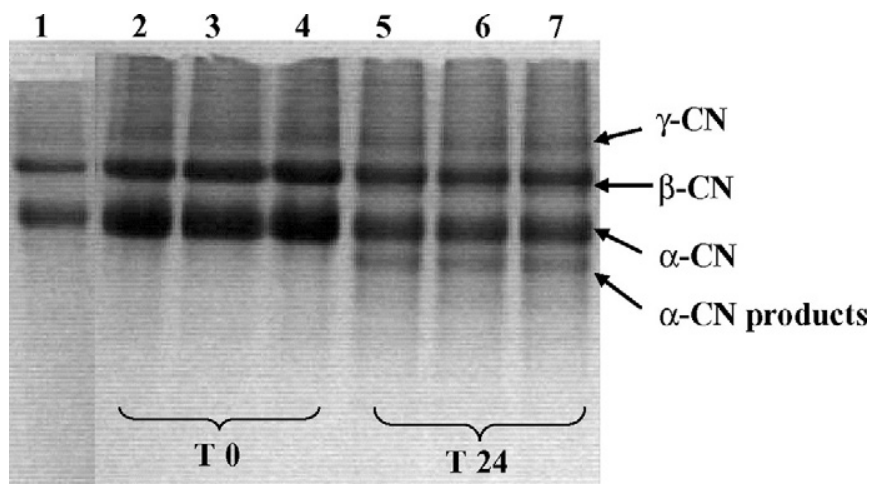

Figure 1. Urea PAGE of Na caseinate incubated with lysed macrophages at 0 and $24 \mathrm{~h}$ at $37^{\circ} \mathrm{C}$. Lane 1: ovine Na caseinate purified. Lanes 2 and 5: protein profiles at 0 and $24 \mathrm{~h}$ after incubation, in early lactation. Lanes 3 and 6: protein profiles at 0 and $24 \mathrm{~h}$ after incubation, in mid lactation. Lanes 4 and 7: protein profiles at 0 and $24 \mathrm{~h}$ after incubation, in late lactation.
u-PA associated with milk neutrophils and t-PA to total PA activity in sheep milk.

Plasmin and PA were affected by stage of lactation $(P<0.001$, Table 2$)$; higher values of PL activity were recorded in early $(42.1 \mathrm{U} / \mathrm{mL})$ than in mid $(31.3 \mathrm{U} / \mathrm{mL})$ and in mid than in late $(28.2 \mathrm{U} / \mathrm{mL})$ lactation milk. In contrast, the highest PG activity values were detected in mid lactation compared with early and late lactation. Both PA (t-PA and u-PA) can convert the proenzyme PG to active PL (Politis, 1996). The PL-PG system in ewe milk is mainly influenced by stage of lactation and number, type, and activity of milk somatic cells (Albenzio et al., 2004). The reduction in PL activity registered in the mid and late lactation milk resulted in an increase in the PG:PL ratio that indicates PG activation efficiency (Weng et al., 2006). In cows, evidence exists of a relationship between the activation of the PL-PG system and the gradual involution of the mammary gland, which occurs during the decline phase of lactation and is controlled by physiological factors connected to the tissue remodeling processes (Flint et al., 2005). Bianchi et al. (2004) observed an increase in PL activity and a decrease in PG activity as lactation progressed in individual hand-milked samples from Sardinian ewes. Albenzio et al. (2004) found a decrease in PL activity during lactation with individual machine-milked Comisana ewes. The results on PL activity of the present

Table 3. Changes (\%) in $\mathrm{CN}(\alpha-$ and $\beta-\mathrm{CN})$ and $\mathrm{CN}$ degradation products $(\gamma-\mathrm{CN}$ and $\alpha$-CN products) after $24 \mathrm{~h}$ of incubation of lysed macrophages on $\mathrm{Na}$ caseinate

\begin{tabular}{lrrrrr}
\hline & \multicolumn{3}{c}{ Stage of lactation } & & \\
\cline { 2 - 4 } Item & Early & Mid & Late & SEM & Effect \\
\hline$\gamma$-CN & 1.0 & 0.7 & 1.6 & 0.47 & NS \\
$\beta$-CN & 11.4 & 10.9 & 9.8 & 0.45 & NS \\
$\alpha$-CN & -20.2 & -19.9 & -19.2 & 0.5 & NS \\
$\alpha$-CN products & $8.5^{\mathrm{a}}$ & $8.2^{\mathrm{ab}}$ & $7.8^{\mathrm{b}}$ & 0.17 & $*$ \\
\hline
\end{tabular}

${ }^{\mathrm{a}, \mathrm{b}}$ Means within a row with different superscripts differ $(P<0.05)$. $* P<0.05$. 
trial carried out on ewe bulk milk agree with findings on individual ewe milk. Results from Flint et al. (2005) and Bianchi et al. (2004) may not be comparable with the present results, because the former were obtained in bovine milk and the latter in a different sheep breed. The PL system behaves individually in different species or breeds, and it was reported that mammary gland involution has considerable interspecies differences. Indeed, although in cows an overlap between lactation and gestation occurs, sheep are nongestating at drying off (Lamote et al., 2004). Plasmin activity, however, is the result of the balance between the actions of activators and inhibitors. The reduction of PG conversion into $\mathrm{PL}$ is not easy to explain; a possible explanation could be the increase in milk of PAI, such as retinoic acid, glucocorticoids, $\beta$-LG, $\alpha$-LA, $\alpha 1$-antitrypsin, and $\alpha 2$ macroglobulin, as suggested by Le Roux et al. (2003). As an alternative, the decrease in PG activity during the last stage of lactation could be attributed to the reduced transfer of $\mathrm{PG}$ from blood to milk. The functional state of the mammary gland and the hormone actions are the main regulators of molecular transfers in milk. McManaman and Neville (2003) reported that exogenous substances can be transferred from blood to milk directly through paracellular pathways or indirectly through the transcytosis pathway, which includes the transport of serum proteins, albumin, hormones, and cytokines. Finally, according to Weng et al. (2006), local factors involved in the regulation of PG activation cannot be excluded.

\section{CONCLUSIONS}

In ewe bulk milk from healthy flocks, the enzymes associated with macrophages hydrolyze $\mathrm{CN}$ according to macrophages levels during lactation, whereas the contribution of macrophages to the regulation of the PL-PG system is independent of macrophage concentrations and stage of lactation. In addition, the activity of u-PA associated with macrophage cells only minimally contributed to total PA activity in milk. It would be interesting to further investigate the different role played by the other components of the PA system (i.e., u-PA associated with milk neutrophils and t-PA) on PL activity in sheep milk during lactation.

\section{ACKNOWLEDGMENTS}

We thank Concetta Perilli, Stefano D'Urso, and Giselda Flaminio for expert technical assistance.

\section{REFERENCES}

Albenzio, M., M. Caroprese, R. Marino, A. Santillo, L. Taibi, and A. Sevi. 2004. Effects of somatic cell count and stage of lactation on the plasmin activity and cheese-making properties of ewe milk. J. Dairy Sci. 87:533-542.

Albenzio, M., A. Santillo, M. Caroprese, R. Marino, P. Centoducati, and A. Sevi. 2005. Effect of different ventilation rates on ewe milk and Canestrato Pugliese cheese quality in summer. J. Dairy Res. 72:447-455.

Andrews, A. T. 1983. Proteinases in normal bovine milk and their action on caseins. J. Dairy Res. 50:45-55.

Baldi, A., G. Savoini, F. Cheli, F. Fantuz, E. Senatore, L. Bertocchi, and I. Politis. 1996. Changes in plasmin-plasminogen activator system in milk from Italian Friesian herds. Int. Dairy J. 6:1045-1053.

Bianchi, L., A. Bolla, E. Budelli, A. Caroli, C. Casoli, M. Paeselli, and E. Duranti. 2004. Effect of udder heath status and lactation state on the characteristics of Sardinia ewe milk. J. Dairy Sci. $87: 2401-2408$.

Blakesley, R. W., and J. A. Boezi. 1977. A new staining technique for proteins in polyacrylamide gels using Coomassie Brilliant Blue G250. Anal. Biochem. 82:580-582.

Caroprese, M., L. Schena, A. Marzano, G. Caternolo, A. Muscio, and M. Albenzio. 2006. Applicazione Di Una Tecnica Immunomagnetica Per L'isolamento Di Macrofagi Nel Latte Ovino. Page 144 in Proc. XVII Meet. Soc. Ital. Patol. Allev. Ovini and Caprini, Lamezia Terme, Italy.

Christensen, S., T. Wiegers, J. Hermansen, and L. Sottrup-Jensen. 1995. Plasma-derived protease inhibitors in bovine milk. Int. Dairy J. 5:439-449.

Flint, D. J., M. Boutinaud, E. Tonner, C. J. Wilde, W. Hurley, P. A. Accorsi, A. F. Kolb, C. B. Whitelaw, J. Beattie, and G. J. Allan. 2005. Insulin-like growth factor binding proteins initiate cell death and extracellular matrix remodeling in the mammary gland. Domest. Anim. Endocrinol. 29:274-282.

IDF. 1993. Determination of nitrogen content. Standard no. 20B. Int. Dairy Fed., Brussels, Belgium.

IDF. 1995. Enumeration of somatic cells. Standard no. 148A. Int. Dairy Fed., Brussels, Belgium.

Kelly, A. L., and P. L. McSweeney. 2003. Indigenous proteinases in milk. Adv. Dairy Chem. 1:494-519.

Korycka-Dahl, M., B. Ribadeau Dumas, N. Chene, and J. Martal. 1983. Plasmin activity in milk. J. Dairy Sci. 66:704-711.

Lamote, I., E. Meyer, A. M. Massart-Len, and C. Buvernich. 2004. Sex steroids and growth factors in the regulation of mammary gland proliferation, differentiation, and involution. Steroids 69:145-159.

Le Roux, Y., F. Laurent, and F. Moussaoui. 2003. Polymorphonuclear proteolytic activity and milk composition change. Vet. Res. 34:629-645.

McManaman, J. L., and M. C. Neville. 2003. Mammary physiology and milk secretion. Adv. Drug Deliv. Rev. 55:629-641.

Mulvihill, D. M., and P. F. Fox. 1977. Proteolysis of $\alpha_{\mathrm{s} 1}$-casein by chimosin: Influence of $\mathrm{pH}$ and urea. J. Dairy Res. 44:533-540.

Nielsen, S. S. 2003. Plasmin system in milk. Pages 929-934 in Encyclopedia of Dairy Sciences. Vol. 2. H. Roginski, J. W. Fuquay, and P. F. Fox, ed. MPG Books Ltd., Bodmin, Cornwall, UK.

Politis, I. 1996. Plasminogen activator system: Implication for mammary cell growth and involution. J. Dairy Sci. 79:1097-1107.

Politis, I., I. Bizelis, and E. Rogdakis. 2002. The urokinase-plasminogen activator system in ovine macrophages and neutrophils. Small Rumin. Res. 44:17-23.

Politis, I., S. Zhao, B. W. McBride, J. H. Burton, and J. D. Turner. 1991. Plasminogen activator production by bovine milk macrophages and blood monocytes. Am. J. Vet. Res. 52:1208-1213.

SAS Institute. 1999. SAS User's Guide: Statistics. Version 8.1 ed. SAS Inst. Inc., Cary, NC.

Sevi, A., M. Albenzio, L. Taibi, D. Dantone, S. Massa, and G. Annicchiarico. 1999. Changes of somatic cell count through lactation and their effects on nutritional, renneting and bacteriological characteristics of ewe's milk. Adv. Food Sci. 21:122-127.

Sevi, A., M. Albenzio, R. Marino, A. Santillo, and A. Muscio. 2004. Effects of lambing season and stage of lactation on ewe milk quality. Small Rumin. Res. 51:251-259. 
Sevi, A., L. Taibi, M. Albenzio, G. Annicchiarico, R. Marino, and M. Caroprese. 2003. Influence of ventilation regimen on microenvironment and on ewe welfare and milk yield in summer. Ital. J. Anim. Sci. 2:197-202.

Sidelmann, J. J., J. Gram, J. Jespersen, and C. Kluft. 2000. Fibrin clot formation and lysis: Basic mechanisms. Semin. Thromb. Hemost. 26:605-618.
Silanikove, N., U. Merin, and G. Leitner. 2005. Physiological role of indigenous milk enzymes: An overview of an evolving picture. Int. Dairy J. 16:533-545.

Weng, M. H., J. Chang, W. Y. Chen, W. K. Chou, H. C. Peh, M. C. Huang, M. T. Chen, and H. Nagahata. 2006. Contribution of somatic cell-associated activation of plasminogen to caseinolysis within the goat mammary gland. J. Dairy Sci. 89:2025-2037. 